\title{
The European Union (EU) Defence Collaboration and the Libyan Crisis: Implications on EU's Interventionism
}

\author{
Nare Hilary ${ }^{1, *} \&$ Hamauswa Shakespear ${ }^{2}$ \\ ${ }^{1}$ Department- Political and Administrative Studies, University of Zimbabwe, Harare, Zimbabwe \\ ${ }^{2}$ Political and Administrative Studies, Mulungushi University, Kabwe, Zambia \\ *Correspondence: Political and Administrative Studies, University of Zimbabwe, Harare, Zimbabwe. E-mail: \\ hilarynare@gmail.com
}

Received: August 3, 2017 Accepted: August 31, $2017 \quad$ Online Published: November 18, 2017

doi:10.5430/wjss.v5n1p29 URL: https://doi.org/10.5430/wjss.v5n1p29

\begin{abstract}
This study analyses the controversy and decidedly mixed views surrounding the EU defence collaboration in the $21^{\text {st }}$ Century. It investigates on the $21^{\text {st }}$ Century challenges faced by the EU in its defence collaboration and its implications on interventionism. The EU defence collaboration was initially developed by historically fractious Western European states in the late 1940s as a response to growing threats posed by the Soviet Union. The EU defence collaboration through-out the 90 s showed some commendable level of unity which has since taken a paradigm shift in the $21^{\text {st }}$ Century. Thus, the EU defence collaboration is deteriorating and needs to be revitalized before the situation goes out of hand. Primary data analysis was used to solicit relevant data and thematic analysis was used to analyse data obtained. The findings showed that, there is lack of unity of purpose among member states in carrying out their defence mandates, lack of commitment by member states to meet their financial obligations requisite for effective and efficient defence collaboration and lack of trust among member states as the major limitations to the effective defence collaboration as member states are skeptical of each other's intentions. Hence, after a critical analysis of the data analysed, this research proposes that the EU should adopt sterner measures to ensure that member states meets their financial obligations and that the EU should be consistent in its policies in order to fulfil its mandates and obligations.
\end{abstract}

Keywords: EU regional integration; increasing insecurities, controversies and uncertainties within the EU

\section{Introduction}

In the face of growing insecurities surrounding Europe and the world at large, the political will of the European Union (EU) in dealing with such issues has not been impressive. While at the Summit of Wales in September 2015, EU leaders pledged to increase their defence spending, the European Leadership Network (ELN) found that 14 European nations had failed to live by their promises (Kearns, 2015). The reluctance is worrisome as the EPSC (2015:1) points out that, in the East, Russia has fundamentally violated the sovereignty of its neighbouring state and regularly violates airspace and territorial waters of European states; "[I]n the Middle East terrorism and war threatens Europe's stability while global-cyber are proliferating..." These developments are pointing to a compromised EU defence pact. Therefore, this study sets out to examine how the seemingly the weaknesses within the EU pact specifically in light of regional body's experiences with the Libyan and Crimean crises will impact on future scenarios that warrant its intervention. This paper advances that the EU's response to the aforementioned cases will have negative implications on future interventionism. Thus, this research investigates the controversies and uncertainty looming within the EU defence collaboration, which can severely affect efforts to pool resources and share military capabilities. The failure of the EU to uphold binding security obligations and to act unanimously due to the complexities faced by member states exposes its vulnerabilities and inabilities to address pressing security problem within and around Europe. 


\section{Theoretical Considerations}

In an effort to unpack and explain the continued fault lines with the EU defence pact and their implications on the regional body's future interventionism, two theories were adapted to complement each other. These are neo-functionalism and neo-realism. The former is useful explaining how the EU started and how integration processes were expanded to include the defence and security while the later provide a framework for identifying certain weaknesses in the regional body's defence pact. This study utilises these two theories based on the assumption that while different theories have been put forward to explain the developments of regional integration processes, no single theory has fully explained the EU integration and its processes satisfactorily.

\subsection{Neo Functionalism and the EU}

The neo-functional theory is one theory in international relations which explains the EU integration though it has often been criticised and at times discredited as of no account and "obsolete". However, Neo functionalism has gone a long way to explain the main factors that led to the formation of the EU and its initial processes and how initial cooperation led to unity and solidarity within the EU. Dosenrode (2010:22) articulates that, "A central concept of the analysis was "spill over"; the claim that agreement on integration in one economic area would overtime cause integration to extend to other policy areas too. Over time the integration would become political." The Neo-functional theory accurately describes how the EU economic cooperation acted as a catalyst of what Europe has become today. The European integration started as an economic integration named the European Coal and Steel Community (ECSS). Devastated by war, European countries realised the advantage of putting their natural resources together to maximize economic benefits. Germany, Belgium, France, Holland Italy and Luxembourg were the original members to this settlement. Anderson (2015: 1) explains that in parallel with the emerging Coal and Steel community the then French Premier Rene Pleven called in October 1950 for a European Defence Command (EDC) and European army under supranational authority. This move signified the "spill over" effect whereby economic cooperation triggered political integration and consequently defence collaboration. It is argued that as integration deepens loyalties will then shift to the new centre. This will give credence to supranational institutions. The defence collaboration was developed to militate against the Union Soviet Socialist Republics (USSR) which was the major threat to Western Europe.

Gehring (1996:228) posits that Neo-functionalists “ $\ldots$ drew attention to the distinction between power issues "high politics" and welfare issues "low politics" and argued that the latter, in contrast with the former, bore the potential for collective pursuit of common interest." To them, low politics would wield political cooperation. According to Gehring (1996:228), "They emphasise the relevance of early institutionalisation of limited cooperation and expected its later expansion; which Haas describe as a "...new political community superimposed over the pre-existing ones." Neo-Functionalist therefore, emphasise the importance of a supranational government which would run or coordinate regional functions. This assumption describes what the EU does today, that is a European supranational Government which effectively administers economic, political and defence activities of European states. Dosenrode (2010:2) states that interests rather than common ideals or identity are the driving force behind the integration process but actors may learn and develop common ideas. The implication is that, common interests act as the glue to binding the entire group together, and mutual benefits help the system to create common policies. The EU today has common policies ranging from economic, political, social and defence policies. The EU has introduced policies such as uniform currency, the Euro zone which works in all the member states of the Union. More so, the EU has adopted the injure one injure all doctrine which is a common defence policy to fight against attacks on one or more of its members. Thus, the supranational body should have competencies and the power to execute common interests and adjudicate in conflict times to facilitate peaceful dispute resolution and maintain cohesion within the Union.

Gehring (1996:228) posits that functionalism and early neo-functionalism rejected both the power orientation of realism and grand design of legalism and traditional institutionalism. Instead they advocated a strategy of institutionally supported incrementalism. However, the theory has been criticised for failure to accommodate the role of member states. Even more problematic the now exclusive focus on the European Community (EC) jeopardises theory building because serious theory cannot be built upon and tested against one and the same empirical case. The failure of neo- functional theory to apply in other contexts has rendered it weak and to some obsolete. Moga (2009, 801) posits that, "... the neo-functionalist tenant dominated the early integration but it soon became obvious that its predictions were insufficient to explain the ebb and flow of the integration process." More-so, the neo functional theory analysed the integration process in European context and did not foresee how the integration would play an active role outside Europe in global politics. Therefore, other theories have been put forward to try and explain the EU integration as the neo- functional theory has proved to be insufficient. 


\subsection{The Neo-Realist Perspective}

To unravel the fault lines within the EU, this research also made use of the neo-realist theory. Snyder (2001) posits that neo-realism, puts survival as the primary goal for nation states. Because states can never be certain of other states' future intentions, there is a lack of trust between states which requires them to be on guard against relative losses of power which could enable other states to threaten their survival. The neo-realist theory accurately paints the state of affairs in European defence collaboration which is now marred with lack of trust and unity in the $21^{\text {st }}$ century. O'donnell (2013:3) explains that "ministries of defence remain nervous about sharing details of their sensitive military technology with allies." This "security dilemma" is straining defence collaboration within the EU and the prospects of a strong unified policy to deal with international crisis when need arise. This has drained a lot or resources for European states as a number of them spend a lot of money developing the same project secretly behind the back of others which instead should be an advantage towards diversity and hence saving resources for other projects. This renders EU weak in its foreign interventionism as it had to rely on the US during the Libyan campaign for air to air refuelling. Thus, the EU on its own is weak, and the neo- realist perspective accurately explains its short falls in the $21^{\text {st }}$ century and this explanation compliments neo realist shortfalls in this research.

\section{The EU's Defence Collaboration: A Synopsis}

European defence collaboration was not a once off process, but it developed over years to be established. The idea of cooperation between and among European states basically started in economic terms. Wilde (2014) argues that, "Europe post war nations were not just after peace, they were also after solutions to economic problems...to solve this six neighbouring countries agreed in the Treaty of Paris to form a free trade area..." The result was the formation of the European Coal and Steel Community (ECSC). The countries involved were, Germany, Belgium, France, Holland, Italy and Luxembourg. Devastated by the Second World War, European nations sought to make peace and take strides to revive their economies to make sure that they would never be drawn back to major wars like the $1^{\text {st }}$ and $2^{\text {nd }}$ World Wars. Wilde (2014) adds that "A false step was taken in the mid 1950's when a proposed European Defence Community among the ESSC was drawn up...The initiation had to be rejected after France's National Assembly voted it down." Therefore, France played a pivotal and decisive role in both the formation of the economic community as well as the defence collaboration since it had a lot of influence in European politics to the extent that its rejection of the ESSC had a bearing on the survival of the attempted settlement in other states involved. Efforts towards a real defence integration started when Western states were faced by an imminent threat to their way of life and ideologies, that is, by the Soviet Union and the confrontation culminated into the Cold War era. The Cold War era was marked by ideological conflict between the United States of America (USA) together with its Western European allies against the Soviet Union.

Anderson (2015:1) points out that, "[T] $]$ he idea of European defence collaboration dates back to the very beginning of integration efforts in Europe at the start of the Cold War." In essence, after the $2^{\text {nd }}$ World War, as Europe was having economic doldrums; Russia had emerged one of the most powerful states in the world and it sought to extend its influence all over Europe and elsewhere in the world. Therefore, to fight against Russian domination the Western states of Europe connived with the USA to counter Russian influence in that region. None of the West European states had the capacity and abilities to unilaterally match USSR's military and economic power, as the Second World War had disrupted economic activities in that part of the Hemisphere. There was no regional hegemony to talk about in Western Europe; hence forming an alliance with the USA was the most viable alternative that the fore-named states had. According to the CVCE (2015:3), "The USSR also offered an ideological, economic and social model extending as never before to the rest of Europe." The war tone Europe was in need of economic aid to revive its troubled economies hence USSR was not only prepared to deal with Europe militarily but sought to use its economic leverage to extend its influence across the forenamed continent. The USSR also sought to have its ideology, that is, communism to be the standard of day to day global practices. Gaining control or influence of activities in war tone Europe would give the USSR economic advantages in terms of trade and overall global power. On the other hand,

The fear of communist expansion in Western Europe was undoubtedly a decisive factor that was just as important as that of conquering new markets. The Americans therefore decided to fight poverty and hunger in Europe, factors they felt encouraged the spread of communism (CVCE, 2015, 28).

Poor economic conditions in Europe in the post war era was a major factor which both states, that is, USSR and the USA, sought to capitalise on in order to gain influence over that part of the Hemisphere. The USA desired to increase its exports through trade with Europe and at the same time contain the USSR. To achieve that end, the USA developed the Marshal Plan which was mainly concerned with dealing with economic hardships in Europe. 
According to CVCE $(2015,28)$ "The Soviet Union rejected the Marshal Plan and persuaded its satellite countries to refuse aid. This rejection deepened the split between the Eastern and Western Europe." In a broad sense, the Cold War was a major conflict which lasted for more than twenty years and it encompassed political, economic and social tension. The intensity of the divide was so great to the extent that it reached other continents like Africa and Asia.

In May 1952, the European Defence Command (EDC) Treaty was signed by Belgium, France, West German, Italy, Luxembourg, and Netherlands supported by the United Kingdom (UK) and the USA. The EDC Treaty, Article 2(3) states that, "Any armed aggression directed against any one of the member states in Europe or against the European Defence Forces shall be considered as an attack directed against all of the member States." Hence the European states embraced the injure one injure all concept, and the EDC treaty in that section was consolidating the North Atlantic Treaty Organisation (NATO) initiatives of collective defence if one or more of their allies were attacked.

Warren (2010) notes that, since its inception in1949, NATO sought to solidify and organise political and military support between the USA and a group of historically fractious European nations in order to deter and if necessary defeat a possible conventional attack from the Soviet Union and later Warsaw Pact. Europe was therefore divided into two blocs the Eastern bloc which was Soviet dominated and Western bloc which was pro America. Thus the formation of NATO was partly a reaction to the ideological conflict between these two major sides. The Soviet Union created the Warsaw Pact as its military alliance to confront the NATO if such action was deemed necessary. As the CVCE (2015: 3) posits “... the Red army unlike the US army was not demobilised at the end of the war. The Soviet Union thus had a real numerical supremacy in terms of man and heavy weapons." Hence, in as much as European states had formed NATO together with the US, the Soviet Union had a considerable upper had since it was not devastated by war as its adversaries were. Europe was in shambles and in total ruin and the Soviet Union sought to use its economic leverage and military strength to pressure Europe to conform to its principles and ideologies.

The Cold War ended peacefully and the US became the sole superpower around 1989. The US Department of State (2010) articulates that by 1980 s, "The Warsaw Treaty Organization was beset by problems related to the economic slowdown in all Eastern European countries Warsaw Pact officially disbanded in 1991..." That marked the end of USSR and its ambitions in Europe, meanwhile; NATO continues up to date and has largely remained relevant in modern day politics though it is besieged by its own problems. Following the end of the Cold War, the EU was formed in 1993 through the Maastricht Treaty on November 1993 (Widle, 2014). The integration of European states into the EU unified or standardised rules and procedures within the Union. Most importantly is the defence collaboration within the EU which continues well after the demise of the USSR and NATO being the principal tool of the EU in its defence. The EU and NATO has developed their mandates not only limited to defence of the EU against territorial attacks on one of its members but also to deal with broad and dynamic world problems like humanitarianism and thwarting acts of aggression elsewhere outside the EU. The EU through NATO has carried out a number of military missions for different purposes of the United Nations (UN) such as the intervention in Bosnia (1992 to 1993) which was basically, a naval blockade aimed at enforcing UN sanctions 1995) Bosnia and Herzegovina (1999) in Kosovo, Afghanistan (2001) against terrorism and more recently Libya in (2011) enforcing the no fly (1973) UN resolution among other missions. The EU has enjoyed a lot of successes at home and in foreign lands. It is argued that the EU managed to promote peace and reconciliation among its member states with the most notable being the reconciliation between France and Germany. As a symbolic validation of its efforts in advancing peace, reconciliation, democracy and human rights, the EU was awarded the Nobel Peace Prize in 2012. Though the EU and NATO have had a lot of achievements within and outside the European continent, the Union is now bedevilled by a number of problems which are affecting efficient operation of its systems and functions. Notably, the EU has had discord with regard to Common Foreign and Treat Policy. This is the area which relates to the EU's deplorable experiences with the Libyan and Crimean crises.

\section{The EU's Response to the Libyan and Crimean Crises}

Despite the forenamed successes and long history of common policies on economic and defence issues, the EU is facing serious constraints in carrying out its mandate in the $21^{\text {st }}$ Century. Controversies and uncertainties within the EU defence collaboration are on the increase, which can limit the organisational capabilities to respond to crisis situations within and outside the continent especially in carrying responsibility to protect. The EU has dynamic mandates ranging from economic, social, political and defence obligations all under the control of a supranational government. According to Lindstrom and Zetterlund (2012:62) "the difficulties both within NATO and the EU in reaching agreement during the Libya crisis ... are causing member states to look for smaller number of likeminded allies." This ongoing process regrouping in pursuit of smaller collaborations with "likeminded" states may affect 
the operations of the EU and NATO as member states are likely to concentrate more on their small group obligations at the expense of collective good of the entire European Union. The division might also make European states weak and vulnerable to diverse threats posed by terrorism from the Middle Eastern States and North Africa which have become a new havens for terrorism. More so, the divisions impairs the EU and NATO's abilities in carrying peace keeping missions and various United Nation Security Council (UNSC) resolutions which should not be left to be the mandate of the USA only.

The Crimean crisis is one classic case in contemporary politics which unravels the level of commitment within the EU defence collaboration to handle and deal with the crisis security situations. Since the global financial crisis hard hit western economies, most EU states introduced austerity measures to adjust their expenditures in the manner compatible with the crisis situation. However, as the Crimean crisis started and unfolded a serious violation of international law; that is an act of aggression by Russia and the EU made commitments it could not live up to just as it did during the Libyan crisis. To deal with Crimean crisis, Kearns (2015) points out that, at the Summit of Wales in September 2015, EU leaders pledged to increase their defence spending but European Leadership Network (ELN) reveals that 14 European nations had failed to live by their promises. These financial contributions were designed to boost military capabilities in dealing with Crimean crisis however, failure by the EU member states to honour and live by their word has compromised the regional body's military capabilities in handling the crisis. Above all, the Pitfalls of the EU reflect the lack of interest not only towards the Crimean crisis but to the calls and interests of the $\mathrm{EU}$ as a regional organisation.

The EPSC (2015:1) posits that, "In the East Russia has fundamentally violated the sovereignty of its neighbouring state and regularly violates airspace and territorial waters of European states. In the Middle East terrorism and war threatens Europe's stability while global-cyber are proliferating..." Thus, the EU leaders are paying a blind eye to imminent threats surrounding European peace and most importantly world peace (due to the spill-over effect of these problems). Thus, spill- over effects in reverse can be a big challenge to the consolidation of regional integration as to the neo-functionalist assumptions that spill-over effect will be a positive factor in leading integration from economy to other areas such as defence. Thus, we argue that spill-over in reverse scenario will happen when the a regional organisation is facing economic and other challenges forcing its member states to consider regrouping in search of alternative security arrangements. The implication is that EU defence collaboration has rather become reactive and not proactive in nature, as its leaders await a grave situation to arise for them to act which could prove to be disastrous for the EU as exemplified by recurring French -terrorist attacks. Therefore, as the Crimean crisis continues, the EU has not taken real action to mitigate the crisis but it is acting as toothless bulldog even though the crisis is at its door step. The EU has slapped Russia with a few sanctions but that has not been adequate to stop Russia and since then nothing significant has been done against an aggressor. With the coming of the Trump Administration and its threats to limit USA's involvement in external crises, the EU might need to rescue its deteriorating defence pact. The wold at large will definitely need super-powers that would check the recalcitrant behaviour of other super powers such as Russia and China.

Furthermore, the Libyan intervention itself has not wielded much, as it was only successful in removing Gaddafi but has destroyed Libya's political, social and economic fabric, as Libya has largely remained chaotic and without a real government in total control. Thus, the Libyan intervention proved to be a major mistake, as it has brought disaster for the Libyan people. The EU did not have a holistic solution to the Libyan crisis as it intervened without a clear road map of temporary systems of governance to facilitate a peaceful transitional period from the conflict to elections and eventually a democratically elected government in total control as the Libyan population clamoured for. Libya has largely remained chaotic 5 years after disposal of Gaddafi hence Libya become a new haven of terrorism as it has no government in control and its people were drawn to a deep economic, political and social crisis due to weak policy framework from both the EU and the UN. Lastly, Britain's exit from the EU, will affect the EU defence collaboration as Britain was one of the key contributors to the defence budget and one of the big four within that system. Therefore, Brexit will complicate and limit EU capabilities in conducting interventionism in grave times. The Breixit itself is a sign that all is not well within the EU and that if the Union fails to revitalise the organisation the Union may face more breakups as other states may also be frustrated with the inefficiencies, bureaupathogies within the system.

\section{Deterioration of the EU Defence Collaboration; Comparison, Signs and Symptoms}

The European Union committed itself to dealing with the Libyan crisis through the $3101^{\text {st }}$ Foreign Affairs Council Meeting in Luxemburg 20 June 2011. Council of the European Union Conclusions on Libya (2011:2) noted that, 
"The EU is unwavering in its commitment to protecting Libyan civilians..." However, as the proceedings unfolded themselves in Libya, EU states did not abide by the agreements made at the forenamed meeting by the Council of the EU. The EU intervention on Libya in 2011 through the NATO initiatives divided the EU as member states did not agree on a single resolution on whether to intervene in Libya or not, despite the resolutions made by the Council of the European Union as explained above. On paper it was convincing, but procedurally lacking. This resulted in Britain and France playing the key role in the implementation of the UN resolution 1973 with the USA "leading from behind", while the majority of the EU states decided not to act. Though this research does not seek to analyse failures and successes of the EU, EU's practices prior the Libyan crisis revealed some degree of unity of purpose as exemplified by its interventionism before the Libyan crisis.

Lampe (2016) points out that, in February 1994, in NATO's first-ever use of force, its fighters shot down four Bosnian Serb aircraft that were violating the UN-imposed no-fly zone over the country. Later that year, at the UN's request, NATO launched isolated and ineffective air strikes against Bosnian Serb targets. In this respect, NATO was acting on humanitarian grounds and not merely to militate against attack on one of its member states as enshrined in the EDC Treaty article 2(3). Thus, its roles had diversified and not only limited to protection of a member state against foreign intervention. Later on, the EU conducted a mission in the Democratic Republic of Congo (DRC) called ARTEMIS. Gergout (2003) explains that, in 2003 EU sent 2000 troops to the North East of the DRC in Bunia, 12 EU member states participated with 5 other none EU states. Though the mission was short lived it managed in realising its goals as it de-escalated violence in Bunia resulting in thousands of its displaced inhabitancy returning home due to the peaceful environment that had been established through EU's actions. Moreover, on July 2004 once again the EU conducted another mission in $\mathrm{BiH}$ and it initially deployed 7000 troops which have since been scaled down to 1,600 troops. A total of 27 countries took part with $22 \mathrm{EU}$ member states and five non EU. In the cases stated above, the EU acted with a commendable degree of unity which has taken a paradigm shift during the Libyan crisis. The actual intervention in Libya was largely done by Britain and France despite the fact that the Council of the EU had declared that the EU would deal with the crisis to the end (Council Conclusion on Libya $3101^{\text {st }}$ Foreign Affairs Council Meeting 2011:1). Furthermore, the EU has acted as toothless bulldog over the ongoing Crimean crisis, which has trivialised the role of the organisation's defence efforts since it has done very little at its "doorstep" against an act of aggression.

\section{Conclusion}

As this paper tried to show, the European defence collaboration is deteriorating and the EU states are slowly fragmenting in terms of centralised defence efforts and Europe is moving into an intermezzo where small islands of defence are becoming the order of the day, which might frustrate interventionism in grave times. More so, there is growing lack of political will among the EU leaders in the face of increasing threats surrounding Europe and other parts of the world which might have spill-over effects into Europe itself. The Libyan crisis revealed fault lines within the EU defence collaboration and the Crimean crisis is revealing the inadequacies of the EU to act even when the problem as at its doorstep. This has revealed weaknesses that were not known prior the Libyan crisis situation, which makes a critical analysis of the circumstances surrounding the EU defence collaboration an important area of research. More-so, the Brexit from the EU reflects on how the peoples of the EU itself lack the unity of purpose which defeats the reason for forming the regional organization in the first place. This paper explored the magnitude of the possible insecurities brought about by the dysfunctional political system and policy inconsistencies within the EU to act collectively inside and out of the European territory during crisis times.

The deterioration of the EU defence collaboration has a bearing not only to the security of the EU itself but it goes beyond EU territory as poor continents like Africa heavily rely on external aid even when conducting humanitarian projects within their own territories. The AU has proved to be incapable of dealing with crisis humanitarian situations on its own, and in that respect, Western states have complimented the AU in carrying out its regional obligations therefore, a weak EU defence system will consequently have effect in grave times in such continents that are greatly dependent on its aid. More so, current security threats like terrorism and cyber networks requires a pro-active approach and defence mechanisms that are solid to avoid great tragedies such as the 9/11.To that effect, the EU needs to make reforms to vitalise its defence initiatives if it is to remain relevant in dealing with the $21^{\text {st }}$ Century security problems. 


\section{References}

Anderson J, J. (2015). EU Defence Collaboration- Back to the Future. Retrieved 15/01/2016 from www.iss.europa.eu/.../european-defence-collaboration-back-to-the-future...

Barbour, R. (2008). Introducing Qualitative Research: A Student Guide to the Craft of Doing Qualitative Research. California. Sage Publications.

EN Council conclusions on Libya - Council of the European Union. [Online]. Retrieved from www.consilium.europa.eu/uedocs/cms_data/docs/pressdata/EN/foraff/125012.pdf [Accessed: 13/01/2016].

CVCE, (2015). The Cold War. (1945-1989).[Online]. Retrieved from www.cvce.eu/content/publication/2011/11/21/.../publishable_en.pdf. [Accessed 15/02/2016]

Dosenrode, S. (2010). Federalism Theory and Neo Functionalism. Elements for an Analytical Framework. [Online]. Retrieved from www.on-federalism.eu/attachments/079-download.pdf. [Accessed: 03/02/16].

Encyclopedia Britannia. 2015. European Union (EU). [Online]. Retrieved from www.britanica.com/topic/European-union. [Accessed: 01/01/2016].

Gehring, T. (1996). Integrating Integration Theory: Neo-Functionalism and International Regimes. Retrieved from www.uni-bamberg.del/.../integrating/integration/-text.pdf. [Accessed: 22/01/2016].

Gergout, C. (2003). Causes and Consequences of the EU's Military Intervention in the Democratic Republic of Congo: A Realist Explanation. [Online]. Retrieved from www.ies.be/.../Gegout,\%20Catherine,\%20Causes\%20and\%20Consequences\%20of\%2. Accessed [09/08/16].

Kearns, I. (2015). Is the Ukrainian Crisis the Kiss of Life or Death for the European Defence Collaboration. Retrieved 03/06/2016 from Europeworld.org/2015/.../Ukraine-crisis-kiss-life-death-european-defence-collaboration...

Lampe. (2016). Bosnian conflict | European history [1992-1995]|Britannica.com [Online]. Retrieved 06/06/16 from https://www.britannica.com/event/Bosnian-conflict

Lindstrom \& Zetterland (2012). Setting the Stage for Military Intervention in Libya- FOI. Retrieved 23/01/2016 from www.foi.se/Global/.../Europa\%20och\%20Nordamerika/foir3498.pdf

Maron, M. (2009). French Military Strategy and NATO Reintegration. [Online]. Retrieved 06/02/2016 from www.cfr.org.France

Mas, A. (2016). Biggest Threat to Europe Now Comes from Libya, not Syria and Iraq. Retrieved 02/06/2016 from www.ibtimes.com/biggest-isis-threat-europe-...

O’Donnell, C, M. (2013). The trials and Tribulations of European Defense Collaboration. Retrieved 04/01/2016 from www.cer.org.uk/sites/default/files/.../pbrief_trialstrib_24july13-7692.pdf

Snyder G, H. (2001). Mearsheimer's World - Offensive Realism and the Struggle for Security. Retrieved 02/07/16 from ir.rochelleterman.com/sites/default/files/glaser\%20review\%20of\%20measheimer.pdf

T, L Moga. (2009). The Contribution of the Neofunctionalist and Intergovernmentalist Theories to the Evolution of the European Integration Process. [Online]. Retrieved 04/01/2016 from www.japss.org/upload/14._mogaarticle.pdf

Turat, D.T.A. (2012). Why Do Realism and Neo Realism Place so Much Emphasis on Anarchy? How important is Anarchy in International Relations? [Online]. Retrieved 05/01/2016 from www.e - ir.infor/2012/02/.../realism-liberalism-and-the possibility of peace...

US Department of State. (2010). Retrieved 04/02/2016 from https://history.state.gov/milestones/1953-1960/warsaw-treaty

Warren, T. (2010). Alliance History and the Future NATO - Brookings Institution. Retrieved 01/05/16 from www.brookings.edu/ /../2010/...nato.../0630 nato alliance warren.pdf

Widle, (2014). History of European Union. Retrieved 02/01/2016 from europeahistory.about .com $>$... $>$ Governmentandlaw 